\title{
Pengembangan Busy Book Berbasis Neurosains dalam Rangka Pengenalan Seks untuk Anak Usia Dini
}

\author{
Desni Yuniarni ${ }^{\bowtie}$ \\ Pendidikan Guru Pendidikan Anak Usia Dini, Universitas Tanjungpura, Indonesia \\ DOI: $\underline{10.31004 / o b s e s i . v 6 i 1.1336}$
}

\begin{abstract}
Abstrak
Penelitian ini bertujuan untuk mengembangkan busy book dalam rangka pengenalan pendidikan seks untuk anak usia dini di Taman Kanak-kanak. Busy book berdasarkan neurosains berisi berbagai macam gambar yang menarik, hal ini sesuai dengan sistem kerja otak, dimana otak akan lebih mudah menangkap informasi dalam bentuk gambar daripada tulisan. Metode yang digunakan dalam penelitian ini adalah model pengembangan dalam penelitian yang mengacu pada model penelitian dan pengembangan 4D (four-D), yang diadaptasikan menjadi 4P yaitu pendefinisian, perancangan, pengembangan, dan penyebaran. Hasil penelitian ini menunjukkan busy book dalam rangka pengenalan pendidikan seks untuk anak usia dini yang dikembangkan oleh peneliti masuk dalam kategori sangat layak yaitu memperoleh skor rata-rata 3,9 dengan skor maksimal 4 dalam hal kesesuaian materi dan memperoleh skor rata-rata 3,5 dengan skor maksimal 4 dalam hal kesesuaian media.
\end{abstract}

Kata Kunci: busy book; neurosains; pengenalan seks; anak usia dini.

\begin{abstract}
The purpose of this research is to develop a busy book in order to introduce sex education for early childhood in kindergarten. Busy books based on neuroscience contain a variety of interesting images, this corresponds to the working system of the brain, where the brain will more easily capture information in the form of images than writing.

The method used in this study is a development model in research that refers to the $4 \mathrm{D}$ (fourD) research and development model, which is adapted into $4 \mathrm{P}$ i.e. definition, design, development, and deployment. The results of this study showed busy book in the framework of the introduction of sex education for early childhood developed by researchers fall into the category of very worthy of obtaining an average score of 3.9 with a maximum score of 4 in terms of material conformity and obtaining an average score of 3.5 with a maximum score of 4 in terms of media conformity.
\end{abstract}

Keywords: busy book; neuroscience; sex recognition; early childhood.

Copyright (c) 2021 Desni Yuniarni

$\square$ Corresponding author :

Email Address : desni.yuniarni@fkip.untan.ac.id (Tanjungpura, Indonesia)

Received 1 May 2021, Accepted 3 Juni 2021, Published 6 June 2021 


\section{PENDAHULUAN}

Berdasarkan fakta yang ada, anak-anak yang menjadi korban sexual abuse adalah anakanak yang masih sangat muda (usia dini). Briggs dan Hawkins (dalam Nuari, 2017) mengungkapkan beberapa penyebab yang membuat anak-anak mudah menjadi sasaran child sexual abuseatau kekerasan seksual, adalah pertama anak-anak mudah mempercayai semua orang dewasa, mereka menganggap bahwa semua orang dewasa akan berbuat baik kepadanya. Kedua, anak-anak usia dini, belum mampu mendeteksi motivasi yang dimiliki oleh orang dewasa ketika berinteraksi dengannya. Mereka belum dapat mendeteksi apabila ada orang dewasa yang memiliki niat tidak baik kepada mereka. Ketiga, anak-anak diajarkan untuk menuruti orang dewasa. Dimana, orang tua adalah orang dewasa yang paling dekat dengan anak dan mereka diajarkan untuk selalu menuruti apapun yang dikatakan oleh orang tua. Keempat, secara alamiah anak-anak memiliki rasa ingin tahu mengenai tubuhnya, dimana anak biasanya meraba atau memegang organ intimnya untuk merasakan sensasi tertentu. Dan kelima, anak-anak diasingkan dari informasi yang berkaitan dengan seksualitasnya. Hal ini berkaitan dengan nilai-nilai yang berlaku di masyarakat, dimana pembicaraan mengenai seksualitas dan alat kelamin cenderung bersifat tabu.

Bagi kebanyakan masyarakat di Indonesia, berbicara mengenai seksualitas adalah hal yang tabu, tidak boleh dibicarakan karena melanggar norm-norma nilai sosial, apalagi membicarakan soal seks kepada anak-anak yang tergolong dini usianya. Pendidikan seks terhadap anak usia dini membutuhkan pendalaman terhadap materi agar tepat sesuai dengan kebutuhan, usia, dan tingkat pemahaman dan kedewasaan anak (Roqib 1970). Oleh karena, materi mengenai pengenalan pendidikan seks untuk anak usia dini harus disusun sedemikian agar dapat dipahami oleh anak dan disesuaikan dengan usia dan tingkat pemahaman anak.

Pemberian materi mengenai pengenalan pendidikan seks untuk anak usia dini di TK dipandang sebagai salah satu cara mengantisipasi terjadinya pelecehan seksual pada anak usia dini. Guru perlu merancang pembelajaran yang berisi pengenalan seks untuk anak didiknya. Salah satu hasil penelitian yang telah dilakukan oleh Solihin (2015), menggambarkan bahwa guru belum sepenuhnya dapat menyusun perencanaan pembelajaran seks berdasarkan langkahlangkah pembuatan perencanaan pembelajaran yang sesuai. Perencanaan pembelajaran merupakan panduan yang dibuat guru dalam melaksanakan kegiatan pembelajaran. Apabila perencanaan yang dibuat belum baik, maka guru akan mengalami kesulitan dalam melaksanakan pembelajarannya di kelas.

Kesulitan dalam melaksanakan pembelajaran di kelas juga terkait pada ketersediaan media pembelajaran yang sesuai dengan pembelajaran yang diberikan. Media pembelajaran adalah sarana penyampaian pesan dalam proses pembelajaran dimana guru berperan sebagai penyampai informasi dan guru seyogyanya dapat menggunakan berbagai media yang sesuai dalam proses pembelajarannya. Media pembelajaran adalah alat bantu dalam proses belajar mengajar. Segala sesuatu yang dipergunakan untuk menstimulasi pikiran, perasaan anak didik, serta dapat menarik perhatian dan kemampuan atau ketrampilan anak didik tersebut sehingga dapat mendorong terjadinya proses belajar (Nurtaniawati 2017). Jadi media pembelajaran memiliki peran yang sangat penting dalam proses pembelajaran untuk anak di TK agar mereka dapat lebih memahami, merasakan, menumbuhkan perhatian, kemampuan maupun keterampilannya terhadap materi pembelajaran yang disampaikan oleh gurunya di kelas.

Namun, pada kenyataannya, belum tersedianya media pembelajaran yang dapat mengenalkan pendidikan seks untuk anak usia dini. Berdasarkan data pra riset yang dilakukan dengan cara wawancara awal yang dilakukan peneliti terhadap beberapa guru TK di kota Pontianak, diperoleh informasi bahwa mereka tidak memiliki media khusus dalam memberikan pembelajaran pengenalan seks untuk anak di TK nya. Salah satu guru di TK Gembala Baik mengatakan bahwa di TK nya belum pernah menggunakan media buku pembelajaran yang khusus mengenalkan pendidikan seks untuk anak usia dini. Pengenalan seks untuk anak 
dilakukan dengan menggunakan buku yang temanya umum dengan disisipkan materi mengenai pengenalan jenis kelamin dan bagaimana menjaga anggota tubuhnya. Kondisi tersebut, membuat penyampaian materi yang diberikan tidak maksimal dan anak-anak kurang antusias dalam kegiatan belajarnya. Guru tersebut mengatakan bahwa buku yang khusus mengajarkan tentang pengenalan seks untuk anak usia dini sangat diperlukan, agar memudahkan guru mengajarkan hal tersebut pada anak-anak di Tknya.

Wawancara lainnya, dilakukan kepada salah satu guru yang sekaligus pengelola di TK Cita Sahabat Mulia. Menurut beliau, di TK nya tidak pernah menggunakan buku khusus untuk mengenalkan pendidikan seks pada anak usia dini karena memang tidak tersedia. Ia pernah melihat buku yang berkaitan tentang hal tersebut, namun buku tersebut diperuntukkan untuk guru dan orang tua, sehingga pembahasannya menggunakan bahasa yang formal yang apabila dijelaskan kepada anak harus dipilih kata-kata yang dapat dipahami anak. Menurutnya, guru perlu memiliki buku khusus tentang pengenalan seks untuk anak usia dini agar dapat dijadikan pegangan atau acuan dalam penyampaian materi tersebut kepada anak. Ia memberikan dukungan yang positif mengenai pentingnya pembuatan buku yang dapat dijadikan media penyampaian informasi untuk mempermudah guru menginformasikan hal tersebut pada anak didiknya di TK.

Guru lainnya yang diwawancarai oleh peneliti adalah salah satu guru di Paud PKK Paritmayor. Guru tersebut mengatakan bahwa mereka tidak pernah mengenalkan pendidikan seks untuk anak usia dini karena tidak memiliki media pembelajaran yang mendukung penyampaian materi tersebut. Mereka mengkhawatirkan munculnya kesalahan dalam penyampaian materi yang diberikan karena tidak adanya panduan atau pedoman mengenai apa saja yang harus disampaikan kepada anak mengenai hal tersebut. Ia menyambut baik keinginan peneliti yang berencana membuat buzy book yang nantinya dapat digunakan sebagai media pembelajaran dalam pengenalan pendidikan seks untuk anak usia dini.

Peneliti juga telah melakukan survey di beberapa toko buku di kota Pontianak dan mencari buku-buku yang berkaitan dengan pengenalan pendidikan seks untuk anak usia dini secara online. Namun, dari beberapa buku yang ditemukan peneliti, buku-buku yang berkaitan dengan pendidikan seks untuk anak usia dini adalah buku yang ditujukan khususnya untuk para orang tua dan gurudalam mengenalkan seks untuk anak usia dini. Isi dari buku sebagian besar adalah tulisan dan sangat sedikit sekali terdapat gambarnya. Peneliti juga belum menemukan buku pengenalan pendidikan seks yang ditujukan untuk anak usia dini, yang berisi gambar atau tulisan sederhana yang dapat dipahami oleh anak.

Padahal media pembelajaran, khususnya buku yang berisi pengenalan pendidikan seks untuk anak usia dini, sangat penting peranannya sebagai alat yang mempermudah guru dalam mengenalkan pendidikan seks untuk anak dan juga dapat memudahkan anak memahami materi yang disampaikan oleh gurunya di kelas.

Media pembelajaran yang dirancang dalam penelitian ini adalah media yang berbentuk busy book berbasis neurosains. Busy book adalah sebuah buku yang terbuat dari kain flanel yang berwarna-warni, berisi aktivitas/kegiatan sederhana yang dapat dilakukan oleh anak sehingga anak dapat terlibat langsung dalam proses pembelajarannya. Guru dapat mengenalkan pendidikan seks untuk anak dengan memberikan materi sesuai dengan aktivitas/kegiatan yang terdapat di dalam busy book, dimana anak dapat memahami materinya dan merasa senang dengan pembelajarannya, dengan adanya sejumlah aktivitas yang harus dilakukannya sendiri dalam busy book.

Penggunaan media busy book berbasis neurosains tersebut juga sejalan dengan tahapan perkembangan kemampuan berpikir anak usia dini. Menurut Piaget (Ibda 2015), anak usia dini berada pada rentang usia 2-7 tahun dimana pada usia ini, tahapan perkembangan kognitifnya berada pada tahapan praoperasional.Pada tahap ini anak membangun pengetahuannya dengan cara merasakan, melakukan dan terlibat langsung dalam aktivitas pembelajarannya. Anak pada usia ini akan memahami pembelajaran yang diberikan apabila menggunakan media yang 
kongkrit, sehingga mereka dapat melakukan, merasa, meraba dan bereksplorasi terhadap media yang diberikan.

Penggunaan media yang kongkrit seperti busy book berbasis neurosains, selain memudahkan mereka dalam memahami materi yang sedang disampaikan oleh guru, juga akan menambah minat anak dalam belajar, karena berisi lembaran buku yang terbuat dari kain flanel yang lembut dan berwarna-warni dengan serangkaian aktivitas yang menyenangkan bagi anak. Sehingga diharapkan dengan menggunakan busy book, anak-anak akan lebih memahami dan fokus pada pembelajaran yang disampaikan guru di kelas.

Berdasarkan hal tersebut, maka peneliti merancang pembuatan media pembelajaran yang menarik dan sesuai dengan perkembangan kognitif anak, berbentuk busy book berbasis neurosains dalam rangka mengenalkan pendidikan seks untuk anak usia dini di TK.

Berdasarkan latar belakang masalah diatas, maka masalah umum dalam penelitian ini adalah bagaimana mengembangkan busy book dalam rangka pengenalan pendidikan seks untuk anak usia dini di Taman Kanak-kanak. Tujuan umum dalam penelitian ini adalah untuk mengembangkan busy book dalam rangka pengenalan pendidikan seks untuk anak usia dini di Taman Kanak-kanak. Busy book adalah sebuah media pembelajaran yang interaktif, terbuat dari kain (terutama flanel) yang dibentuk menjadi sebuah buku dengan warna warna cerah, berisi aktivitas permainan sederhana (Mufliharsi 2017).

Pembelajaran dengan menggunakan busy book memiliki beberapa keunggulan, yakni, guru mudah menentukan materi ajar, tinggal mengikuti materi yang terdapat pada busy book, guru dapat dengan mudah mengevaluasi anak didiknya karena dengan sendirinya aktivitas yang terdapat di dalam buku dapat mengeksplorasi kemampuan masing-masing anak didik, anak didik tanpa diminta, melakukan aktivitas yang dituntut dilakukan di dalam busy book, akan timbul rasa ingin tahu dari para anak didik dan cenderung langsung melakukan sendiri tanpa pertolongan dari guru, sifat media tahan lama karena terbuat dari kain sehingga tidak gampang kotor, kusut, maupun robek, proses pembelajaran di kelas menjadi menyenangkan dan anak secara aktif terlibat langsung dalam pembelajaran, pembelajaran menjadi menyenangkan karena banyak warna, banyak aktivitas, dan memancing kreativitas anak didik untuk melakukan aktivitas yang ada menjadi lebih baik dan sistematis Busy book berbasis neurosains adalah busy book yang dirancang berdasarkan teori-teori yang berkaitan tentang kinerja otak. Dimana penelitian ini memfokuskan pada teori-teori yaitu teori mengenai gaya belajar.

Terdapat tiga modalitas (type) dalam gaya belajar yaitu visual, auditorial dan kinestetik (Arylien Ludji Bire 2014). Banyak ahli lainnya yang mengategorikan gaya belajar berdasarkan preferensi kognitif, profil kecerdasan dan preferensi sensori. Dalam penelitian ini, peneliti menggunakan preferensi sensori yaitu gaya belajar visual, auditorial, dan kinestetik. Alasan digunakannya preferensi sensori karena dalam proses kegiatan belajar anak didik dapat diamati secara langsung melalui alat indera. Berdasarkan preferensi sensori, pelajar visual belajar melalui sesuatu yang mereka lihat, auditorial belajar dengan cara mendengar, dan kinestetik belajar dengan gerak, bekerja, dan menyentuh. Setiap anak didik memiliki ketiga gaya belajar tersebut, hanya saja satu gaya biasanya lebih mendominasi. Busy book berbasis neurosains yang dirancang dalam penelitian ini adalah busy bookyang berisi berbagai macam aktivitas/kegiatan pembelajaran yang dapat memfasilitasi gaya belajar anak yang berbeda-beda.

Verba-grafis, memori di otak akan tertata dengan baik, efektif dan efisien jika diformulasikan dalam bentuk kata dan gambar. Media gambar bersifat kongkret karena anak dapat melihat benda secara nyata dalam bentuk tiruan, sehingga anak tidak salah membayangkan suatu benda. Media gambar juga dapat mengatasi ruang dan waktu karena dengan media gambar guru tidak perlu mengajak anak ke tempat pembelajaran langsung, misal guru menjelaskan macam-macam binatang tidak perlu harus pergi ke kebun binatang tetapi cukup dengan menggunakan gambar sebagai media pembelajarannya, hal ini juga untuk mengatasi keterbatasan masalah dan keterbatasan pengamatan. Media gambar dinilai murah karena dalam mendapatkan gambar cukup mudah, guru menggunakan foto atau mendownload 
di internet (Saputri 2015). Di dalam busy book terdapat kata-kata sederhana dan singkat yang cocok untuk anak usia dini dan gambar-gambar yang menarik penuh warna-warni

Pendidikan seks dimaksudkan disini adalah agar anak memahami akan kondisi tubuhnya, kondisi tubuh lawan jenisnya, serta menjaga dan menghindarkan anak dari kekerasan seksual (Jatmikowati, Angin 2015). Menurut Listiyana (2010), pendidikan seks usia dini dapat memberikan pemahaman anak akan kondisi tubuhnya, pemahaman akan lawan jenisnya, dan pemahaman untuk menghindarkan dari kekerasan seksual.

Berdasarkan pendapat para ahli diatas, dapat disimpulkan bahwa pengenalan seks pada anak dapat dimulai dari pengenalan mengenai anggota tubuh. Setelah itu dapat dilakukan dengan cara mengajarkan mereka membersihkan diri sendiri dan membersihkan alat kelamin sendiri. Pendidikan ini pun secara tidak langsung dapat mengajarkan anak untuk tidak sembarangan mengizinkan orang lain membersihkan, bahkan menyentuh alat kelaminnya,apa yang harus dilakukan apabila ada orang lain yang menyentuh alat kelaminnya. Cara menyampaikan pendidikanseksual itu pun tidak boleh terlalu vulgar karena justru akan berdampak negatif pada anak.

Menurut Hermawan (dalam Wahyuni, 2018), terdapat 4 manfaat yang diperoleh anak dengan mengenalkan pendidikan seks untuk anak usia dini, adalah pertama; anak akan memahami perubahan-perubahan yang terjadi pada dirinya. Perubahan yang dimaksud adalah adanya perbedaan bentuk dan ukuran tubuh ketika anak masih bayi dengan ketika mereka menjadi anak-anak, kedua; anak mendapat pengetahuan tentang fungsi organ reproduksi, bagaimana merawatnya dan menjaga kebersihannya. Pada anak yang sudah dapat buang air besar dan buang air kecil sendiri, mereka sudah dapat membersihkan alat genetalnya. Dengan membersihkan sendiri, akan mengurangi resiko anak untuk dibersihkan alat genetalnya oleh orang lain, dan mengurangi resiko pelecehan seksual yang dilakukan oleh orang lain. Ketiga, mendapatkan pengetahuan dan pemahaman mengenai etika dan berbagai perilaku seksual yang menyimpang dan harus dihindari. Anak diajarkan mengenai bagian tubuh mana saja yang tidak boleh disentuh oleh orang lain, sehingga apabila ada orang lain yang menyentuhnya, anak tahu bagaimana cara menghindari dan mengatasinya. Keempat, memahami berbagai akibat dari penyalahgunaan alat reproduksi yang akan membahayakan kesehatannya baik secara fisik maupun psikis. Dengan pengenalan pendidikan seks, anak akan memahami bahwa alat reproduksinya adalah miliknya sendiri dan tidak boleh ada siapapun yang menyentuhnya. Anak memiliki keberanian untuk menghindar atau menolak siapapun yang berniat melecehkannya secara seksual.

\section{METODOLOGI}

Penelitian ini bertujuan untuk mengembangkan suatu produk berbentuk busy book berbasis neurosains yang bertujuan untuk mengenalkan pendidikan seks untuk anak usia dini. Oleh karena itu, metode penelitian yang dilakukan berbentuk model penelitian dan pengembangan. Dipilihnya metode penelitian berbentuk model penelitian dan pengembangan dalam penelitian ini adalah agar busy book berbasis neurosains yang bertujuan untuk mengenalkan pendidikan seks untuk anak usia dini ini dapat didefinisikan dengan baik, dirancang, dikembangkan dan disebarkan kepada masyarakat agar dapat bermanfaat bagi yang membutuhkan, sesuai dengan tujuan penelitian. Model pengembangan dalam penelitian ini mengacu pada model penelitian dan pengembangan 4D. Menurut Triyanto (dalam Sari, 2016), model pengembangan 4D yaitu define, design, develop, dan disseminate dapat diadaptasikan menjadi $4 \mathrm{P}$ yaitu pendefinisian, perancangan, pengembangan, dan penyebaran.

Partisipan dalam penelitian ini adalah guru-guru di TK Immanuel 2, TK Bina Sari dan TK Aisyah 3 di kota Pontianak. Dipilihnya para guru TK tersebut sebagai partisipan dalam penelitian ini adalah karena guru dapat menjadi fasilitator dalam mengenalkan pendidikan untuk anak usia dini melalui media berbentuk busy book berbasis neurosains kepada anak usia dini. Secara umum, partisipan yang akan diikutsertakan dalam penelitian ini memiliki 
karakteristik yaitu, berstatus sebagai guru tetap di TK, memiliki pengalaman bekerja lebih dari 5 tahun, memiliki latar belakang pendidikan sarjana pendidikan guru anak usia dini dan telah mendapatkan sertifikat sertifikasi guru.

Selain diberikan kepada para guru-guru tersebut, dilakukan uji coba produk berbentuk busy book berbasis neurosains kepada para anak TK A (usia 4-5 tahun) di TK Immanuel 2 Pontianak yang berjumlah 22 orang anak. Sumber data dalam penelitian ini juga melibatkan dosen prodi PG PAUD, FKIP UNTAN, dosen Psikologi di IAIN Pontianak dan para guru di 3 TK tersebut untuk mendapatkan data validasi ahli media dan ahli materi. Metode pengumpulan data merupakan langkah utama dalam penelitian, dengan maksud untuk mendapatkan data yang akurat dan dapat dipertanggung jawabkan. Menurut Sugiyono (dalam Kusnadi \& Mutoharoh, 2016) mengatakan ada empat macam metode pengumpulan data; yaitu observasi, wawancara, dokumentasi, dan gabungan/triangulasi.

Mengacu pada Sugiyono (dalam Prasanti, 2018), penelitian ini menggunakan metode pengumpul data, yaitu wawancara. Metode ini digunakan ketika peneliti melakukan ujicoba produk untuk melihat dan mengetahui keefektifan media yang dikembangkan untuk mendapatkan data mengenai kelebihan dan kelemahan produk yang dari data tersebut akan dilakukan revisi atau perbaikan produk. Selain wawancara juga dilakukan angket/kuesioner. Metode ini digunakan peneliti untuk mendapatkan data berupa uji validitas atau kelayakan busy book berbasis neurosains dari segi materi maupun segi kelayakan media yang digunakan untuk anak usia dini dan dapat mencapai tujuan dari pengembangan produk.

Teknik analisis data yang digunakan dalam penelitian ini adalah teknik analisis deskriptif yang dilakukan dengan menggunakan statistik deskriptif. Teknik analisis data yang digunakan dalam penelitian ini adalah teknik analisis kualitatif dan analisis kuantitatif. Analisis kualitatif digunakan untuk mendeskripsikan hasil observasi, wawancara, saran dosen validasi, dan catatan dokumentasi saat diimplementasikan. Data tersebut dianalisis secara deskriptif kualitatif, beberapa saran akan digunakan untuk perbaikan produk pada tahap revisi sedangkan catatan dokumentasi dideskripsikan untuk menggetahui efektifitas produk yang dikembangkan saat digunakan dalam pembelajaran dimana dalam penelitian ini terkait dengan respon saat menggunakan busy book tersebut. Analisis kuantitatif digunakan untuk mendeskripsikan kualitas media berdasarkan penilaian guru TK. Teknik kualitatif dilakukan dengan pemberian kriteria yang diadopsi dari Siyoto Sandu (2015). Penelitian ini akan melakukan dua tahap analisis yaitu menentukan nilai rata-rata yang di peroleh dan membuat kriteria menjadi 4 kriteria, yaitu, sangat layak, layak, kurang layak, dan tidak layak.

\section{HASIL DAN PEMBAHASAN}

Hasil dari penelitian ini akan diuraikan sesuatu dengan yang telah direncanakan. Adapun hasil dari setiap pelaksaan penelitian tersebut yaitu;

Tahap pertama tahap Pendefinisian.Tahap pendefinisian ini terdiri dari beberapa bagian, yaitu pendefinsian busy book berbasis neurosains. Pada tahap ini telah ditetapkan mengenai definisi media yang digunakan dalam pengenalan pendidikan seks untuk anak usia dini dalam penelitian ini yaitu media berbentuk busy book berbasis neurosains. Busy book berbasis neurosains adalah sebuah buku yang terbuat dari kain flanel yang lembut dan berwarna-warni, berisi aktifitas-aktifitas sederhana seperti mengancingkan baju, menempel kain yang dibelakangnya terdapat perekat, menyocokkan gambar dengan tulisan dan serangkaian aktifitas lainnya yang menarik perhatian anak dan membuat mereka senang dalam aktivitas yang terdapat dalam busy book ini, dimana anak terlibat langsung dalam proses pembelajarannya. Busy book ini juga dapat mengeluarkan suara apabila anak menekankan bagian tubuh yang tidak boleh disentuh oleh orang lain, seperti mulut, dada, alat kelamin perempuan/laki-laki dan bokong. Suara yang dikeluarkan adalah suara anak laki-laki dan suara anak perempuan, contohnya pada halaman yang ada gambar anak laki-laki, kemudian ditekan bagian alat kelamin laki-lakinya, maka akan keluar suara yang mengucapkap kata "Tidak". Hal sama juga 
terjadi pada saat kita menekan 4 bagian yang tidak boleh disentuh oleh orang lain pada gambar anak perempuan. Busy book ini juga dilengkapi dengan buku petunjuk yang berisi bagaimana cara menggunakan busy book, sehinggaguru yang mendampingi anak dalam menggunakan buku ini dapat mengetahui tujuan diberikannya buku ini dan bagaimana memberi penjelasan kepada anak mengenai setiap aktifitas yang terdapat di dalamnya, sehingga tujuan pembuatan buku ini dapat tercapai.

Dikatakan berbasis neurosains maksudnya busy book dirancang dengan pendekatan yang ada dalam hukum dasar otak yang relevan dalam bidang pendidikan, yaitu prinsip kekhususan, dimana kemampuan otak berkaitan dengan kekhususan seseorang dalam memanfaatkannya. Busy book menghargai keunikan gaya belajar setiap anak (visual, audio, kinestetik), dimana seluruh aktivitas dalam busy book dapat memfasilitasi gaya belajar anak yang berbeda-beda, yaitu gaya belajar visual dapat terfasilitasi melalui berbagai bentuk gambar anak laki-laki maupun perempuan yang menggunakan pakaian dan aksesoris yang berwarnawarna. Selain itu juga terdapat beberapa replika benda-benda yang berfungsi untuk menjaga kesehatan tubuh seperti handuk, sikat gigi, odol gigi dan sabun yang menarik bentuk dan warnanya, sehingga anak-anak yang memiliki gaya belajar visual akan lebih mudah memahaminya melalui tampilan visual tersebut.

Gaya belajar auditory difasilitasi melalui penyampaian materi secara verbal yang disampaikan oleh guru ketika mendampingi anak memberikan busy book ini. Selain itu juga anak-anak akan mendengar suara anak laki-laki maupun anak perempuan yang mengatakan "tidak", ketika disentuh 4 bagian tubuhnya yang tidak boleh disentuh oleh orang lain. Melalui suara tersebut, anak dengan gaya belajar auditori akan lebih memahami materi yang disampaikan melalui busy book ini. Selain itu juga, gaya belajar kinestetik dapat terfasilitasi melalui berbagai aktivitas permainan yang bertujuan untuk mengenalkan anak tentang pendidikan seks yang terdapat dalam busy book tersebut, seperti kegiatan memakaikan gambar anak laki-laki dan perempuan baju dan celana/rok, agar tertutup seluruh tubuhnya, sehingga bagian yang tidak boleh dilihat oleh orang lain akan tertutup dan kegiatan menggosok gigi dan mandi yang bertujuan untuk menjaga kebersihan anggota tubuh. Verba-grafis, memori di otak akan tertata dengan baik, efektif dan efisien jika diformulasikan dalam bentuk kata dan gambar. Di dalam busy book terdapat kata-kata sederhana dan singkat yang cocok untuk anak usia dini dan gambar-gambar yang menarik penuh warna-warni.

Tahap kedua adalah tahap penentuan tujuan, yaitu menentukan tujuan pengembangan busy book tersebut, yaitu sebagai media pembelajaran untuk mengenalkan pendidikan seks untuk anak usia dini.

Tahap ketiga adalah tahap menentukan tema yang sesuai dengan kurikulum PAUD. Tema yang sesuai adalah tema tentang tubuhku. Pada saat guru mengajari anak tema tersebut, maka busy book dapat diberikan kepada anak, karena materi yang terdapat dalam busy book sejalan dengan tema tersebut.

Tahap keempat, yaitu tahap penentuan materi, maka materi yang diberikan kepada anak usia dini untuk mengenalkan tentang pendidikan seks adalah materi yang berkaitan dengan kesesuaian materi dengan standar tingkat perkembangan kognitif anak. Kesesuaian tersebut penting dilakukan agar anak memahami materi yang disampaikan kepadanya. Selain itu juga busy book mengandung materi yang dapat mengenalkan pendidikan seks untuk anak seperti pengenalan anggota tubuh, pentingnya menjaga kebersihan tubuh, bagian tubuh yang tidak boleh disentuh dan apa yang harus dilakukan apabila ada orang lain yang menyentuh bagian tersebut. Materi lainnya yang terdapat di busy book adalah kesesuaian materi dengan lingkunp perkembangan anak.

Tahap selanjutnya adalah tahap perancangan. Tahap ini berisi penentuan alur, tokoh dan latar, setelah itu membuat scenario, menyiapkan materi, merancang tulisan, gambar dan suara. Busy book ini memiliki tokoh anak laki-laki dan anak perempuan dengan alur cerita dimana mereka dapat menyebutkan nama-nama anggota tubuhnya, dapat membersihkan dirinya sendiri dan dapat menyebutkan bagian apa saja yang tidak boleh disentuh oleh orang lain. Selain itu 
juga mereka dapat mengatakan "tidak" apabila ada orang lain yang menyentuh 4 bagian tubuhnya yang tidak boleh disentuh tersebut. Adapun hasil dari perancangan dapat dilihat pada gambar 1 sampai dengan 4.

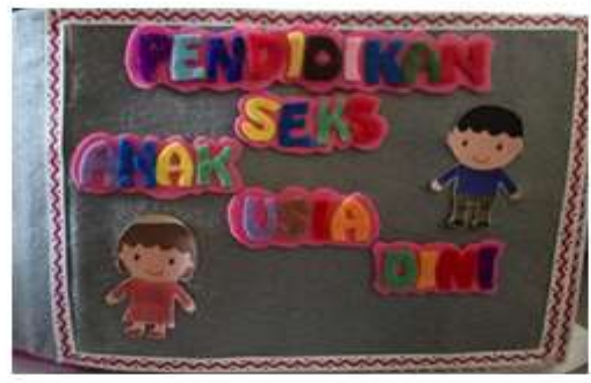

Gambar 1. Cover busy book

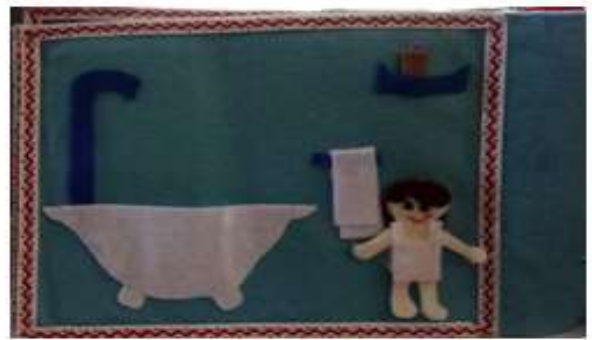

Gambar 3. Menjaga kebersihan tubuh

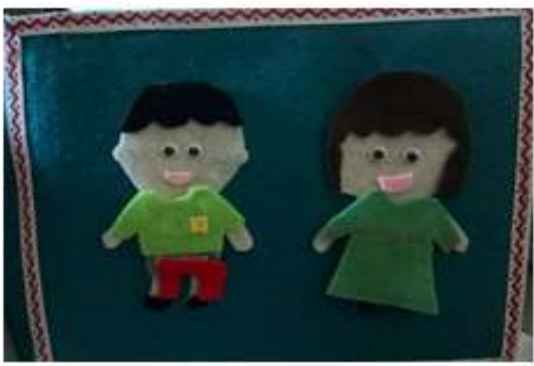

Gambar 2. Perbedaan jenis kelamin

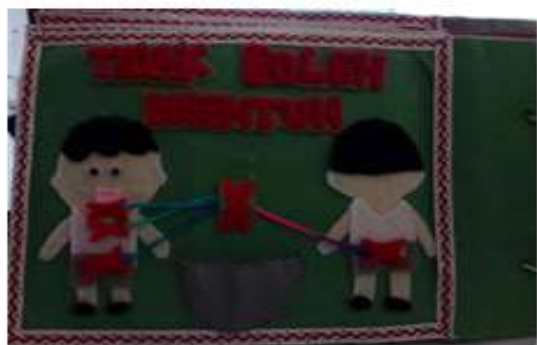

Gambar 4. Bagian tubuh yang tidak boleh disentuh orang lain

Tahap selanjutnya adalah tahap pengembangan. Pada tahap ini peneliti melakukan wawancara dan memberikan angket kepada para guru-guru di TK Immanuel 2, dan TK Aisyah 3 Pontianak untuk mendapatkan data mengenai validasi ahli materi. Sedangkan data validasi dari ahli media diperoleh dari Psikolog anak, dosen di PG-PAUD dan guru di TK Bina Sari Pontianak. Ujicoba produk yaitu busy book dilakukan pada 25 orang anak di TK Immanuel 2 Pontianak.

Hasil uji validasi ahli materi dapat dilihat pada tabel 1.

Tabel 1. Hasil Uji Validasi Ahli Materi

\begin{tabular}{llccc}
\hline No & \multicolumn{1}{c}{ Indikator } & Validator & Validator & Validator \\
& & 1 & 2 & 3 \\
\hline 1 & $\begin{array}{l}\text { Kesesuaian materi dengan standar tingkat } \\
\text { perkembangan kognitif anak }\end{array}$ & 4 & 4 & 4 \\
2 & $\begin{array}{l}\text { Mengandung materi yang dapat mengenalkan } \\
\text { pendidikan seks untuk anak }\end{array}$ & 4 & 4 & 4 \\
$3 \quad \begin{array}{l}\text { Kesesuaian materi dengan lingkup perkembangan anak } \\
\text { Jumlah }\end{array}$ & 3,7 & 3,8 & 3,8 \\
Rata-rata & 11,7 & 11,8 & 11,8 \\
Rata-rata semua validator $=3,9$ & 3,9 & 3,9 & 3,9 \\
\hline
\end{tabular}

Skor maksimal $=4$, skor minimal 1

$$
\begin{array}{r}
\text { Mi }=1 / 2 \times(1+4) \\
=2,5 \\
\text { Sbi }=1 / 6 \times(4-1) \\
=0,5
\end{array}
$$

Rata-rata hasil validasi materi yang diberikan validator menunjukkan bahwa busy book berbasis neurosains dalam rangka pengenalan pendidikan seks untuk anak usia yang dikembangkan oleh peneliti masuk dalam kategori sangat layak. 
Masukan dari beberapa validator mengenai materi yang terdapat di busy book adalah perlunya ditambah materi mengenai dampak yang akan diperoleh anak apabila tidak membersihkan diri dan perlu adanya urutan penyampaian materi yang sistematis agar tidak menimbulkan kebingungan anak dalam memahaminya.

Hasil uji validasi ahli media sebagaimana pada tabel 2.

Tabel 1. Hasil Uji Validasi Ahli Materi

\begin{tabular}{llccc}
\hline No & \multicolumn{1}{c}{ Indikator } & Validator & Validator & Validator \\
& & 1 & 2 & 3 \\
\hline 1 & Kesesuaian dengan prinsip pemilihan media & 3,2 & 3,4 & 4 \\
2 & Kesesuaian dengan fungsi media & 3,5 & 3,7 & 3,8 \\
$3 \quad$ Kesesuaian dengan manfaat media & 2,6 & 3,7 & 3,7 \\
Jumlah & 9,3 & 10,8 & 11,5 \\
Rata-rata & 3,1 & 3,6 & 3,8 \\
Rata-rata semua validator $=3,5$ & & & \\
\hline
\end{tabular}

Skor maksimal $=4$, skor minimal 1

$$
\begin{array}{r}
\mathrm{Mi}=1 / 2 \times(1+4) \\
=2,5 \\
\mathrm{Sbi}=1 / 6 \times(4-1) \\
=0,5
\end{array}
$$

Rata-rata hasil validasi media yang diberikan validator menunjukkan bahwa busy book berbasis neurosains dalam rangka pengenalan pendidikan seks untuk anak usia yang dikembangkan oleh peneliti masuk dalam kategori sangat layak.

Masukan dari beberapa validator mengenai media yang terdapat di busy book adalah perlunya ditambah volume suara boneka yang bisa mengeluarkan suara, karena suaranya relatif pelan, sehingga sulit didengar oleh anak yang jumlahnya banyak dalam 1 kelas. Selain itu juga, tulisan kertas yang terdapat di media sebaiknya di laminating sehingga awet dan tidak mudah robek atau rusak.

Hasil uji coba dilakukan pada 22 orang anak TK A di Immanuel 2 Pontianak. Tujuan dilakukan ujicoba ini adalah untuk mengetahui efektifitas busy book sebagai media dalam

\begin{tabular}{|c|c|c|}
\hline No. & Persentase & Hasil uji coba pada anak \\
\hline 1 & 100 & Anak menunjukkan perhatiannya pada media yang diberikan \\
\hline 2 & 90 & Anak menunjukkan antusias terhadap media yang diberikan \\
\hline 3 & 90 & $\begin{array}{l}\text { Anak menunjukkan keinginan turut berpartisipasi dalam aktivitas } \\
\text { yang ada di media }\end{array}$ \\
\hline 4 & 86 & $\begin{array}{l}\text { Anak dapat menjawab pertanyaan mengenai cara menjaga kebersihan } \\
\text { anggota tubuh }\end{array}$ \\
\hline 5 & 86 & $\begin{array}{l}\text { Anak dapat menyebutkan } 4 \text { bagian anggota tubuh yang tidak boleh } \\
\text { disentuh oleh orang lain }\end{array}$ \\
\hline
\end{tabular}
pengenalan pendidikan seks untuk anak usia dini. Hasil dari uji coba tersebut sebagaimana pada tabel 3 .

Tabel 3. Hasil Uji Coba Media

Dari hasil ujicoba media tersebut, dapat disimpulkan bahwa media busy book berbasis neurosains yang dikembangkan oleh peneliti efektif dalam mengenalkan pendidikan seks untuk anak usia.

Tahap penyebaran, yaitu setelah mendapat masukan dari para validator media maupun materi, busy book tersebut akan diperbaiki, diberikan kepada beberapa TK, di upload ke youtube dan mendapatkan lisensi hak cipta. 


\section{Pembahasan}

Tahap Pendefinisian. Tahap ini terdiri dari beberapa bagian, yaitu pendefinsian busy book berbasis neurosains. Pada tahap ini telah ditetapkan mengenai definisi media yang digunakan dalam pengenalan pendidikan seks untuk anak usia dini dalam penelitian ini yaitu media berbentuk busy book berbasis neurosains.

Busy book berbasis neurosains adalah sebuah buku yang terbuat dari kain flanel yang lembut dan berwarna-warni, berisi aktifitas-aktifitas sederhana seperti mengancingkan baju, menempel kain yang dibelakangnya terdapat perekat, menyocokkan gambar dengan tulisan dan serangkaian aktifitas lainnya yang menarik perhatian anak dan membuat mereka senang dalam aktivitas yang terdapat dalam busy book ini, dimana anak terlibat langsung dalam proses pembelajarannya.

Definisi tersebut sejalan dengan pendapat yang dikemukakan oleh Mufliharsi (2017) yaitu sebuah media pembelajaran yang interaktif, terbuat dari kain (terutama flanel) yang dibentuk menjadi sebuah buku dengan warna warna cerah, berisi aktivitas permainan sederhana.

Busy book ini juga dapat mengeluarkan suara apabila anak menekankan bagian tubuh yang tidak boleh disentuh oleh orang lain, seperti mulut, dada, alat kelamin perempuan/lakilaki dan bokong. Suara yang dikeluarkan adalah suara anak laki-laki dan suara anak perempuan, contohnya pada halaman yang ada gambar anak laki-laki, kemudian ditekan bagian alat kelamin laki-lakinya, maka akan keluar suara yang mengucapkap kata "Tidak". Hal sama juga terjadi pada saat kita menekan 4 bagian yang tidak boleh disentuh oleh orang lain pada gambar anak perempuan.

Busy book ini juga dilengkapi dengan buku petunjuk yang berisi bagaimana cara menggunakan busy book, sehinggaguru yang mendampingi anak dalam menggunakan buku ini dapat mengetahui tujuan diberikannya buku ini dan bagaimana memberi penjelasan kepada anak mengenai setiap aktifitas yang terdapat di dalamnya, sehingga tujuan pembuatan buku ini dapat tercapai.

Dikatakan berbasis neurosains maksudnya busy book dirancang dengan pendekatan yang ada dalam hukum dasar otak yang relevan dalam bidang pendidikan, yaitu prinsip kekhususan, dimana kemampuan otak berkaitan dengan kekhususan seseorang dalam memanfaatkannya. Busy book menghargai keunikan gaya belajar setiap anak (visual, audio, kinestetik), dimana seluruh aktivitas dalam busy book dapat memfasilitasi gaya belajar anak yang berbeda-beda, yaitu gaya belajar visual dapat terfasilitasi melalui berbagai bentuk gambar anak laki-laki maupun perempuan yang menggunakan pakaian dan aksesoris yang berwarnawarna. Selain itu juga terdapat beberapa replika benda-benda yang berfungsi untuk menjaga kesehatan tubuh seperti handuk, sikat gigi, odol gigi dan sabun yang menarik bentuk dan warnanya, sehingga anak-anak yang memiliki gaya belajar visual akan lebih mudah memahaminya melalui tampilan visual tersebut.

Gaya belajar auditory difasilitasi melalui penyampaian materi secara verbal yang disampaikan oleh guru ketika mendampingi anak memberikan busy book ini. Selain itu juga anak-anak akan mendengar suara anak laki-laki maupun anak perempuan yang mengatakan "tidak", ketika disentuh 4 bagian tubuhnya yang tidak boleh disentuh oleh orang lain. Melalui suara tersebut, anak dengan gaya belajar auditori akan lebih memahami materi yang disampaikan melalui busy book ini.

Selain itu juga, gaya belajar kinestetik dapat terfasilitasi melalui berbagai aktivitas permainan yang bertujuan untuk mengenalkan anak tentang pendidikan seks yang terdapat dalam busy book tersebut, seperti kegiatan memakaikan gambar anak laki-laki dan perempuan baju dan celana/rok, agar tertutup seluruh tubuhnya, sehingga bagian yang tidak boleh dilihat oleh orang lain akan tertutup dan kegiatan menggosok gigi dan mandi yang bertujuan untuk menjaga kebersihan anggota tubuh. Prinsip tersebut sejalan dengan gaya belajar yang dikemukakan oleh Arylien Ludji Bire, (2014) yaitu terdapat tiga modalitas (type) dalam gaya belajar yaitu visual, auditorial, dan kinestetik. Oleh karena itu materi yang terkandung dalam 
busy book ini juga berisi berbagai kegiatan yang dapat memfasilitasi ketiga gaya belajar tersebut.

Verba-grafis, memori di otak akan tertata dengan baik, efektif dan efisien jika diformulasikan dalam bentuk kata dan gambar. Di dalam busy book terdapat kata-kata sederhana dan singkat yang cocok untuk anak usia dini dan gambar-gambar yang menarik penuh warna-warni. Pemilihan media yang bersifat verba-grafis tersebut sejalan dengan pendapat yang dikemukakan oleh Saputri (2015), yaitu media gambar dinilai murah karena dalam mendapatkan gambar cukup mudah, guru menggunakan foto atau mendownload di internet. Oleh karena itu media yang digunakan dalam busy book ini bersifat verba-grafis.

Tahap penentuan tujuan, yaitu menentukan tujuan pengembangan busy book tersebut, yaitu sebagai media pembelajaran untuk mengenalkan pendidikan seks untuk anak usia dini. Penentuan tujuan tersebut sejalan dengan pendapat yang dikemukakan oleh Jatmikowati, T. E., Angin, R., \& Ernawati (2015) yaitu pendidikan seks dimaksudkan disini adalah agar anak memahami akan kondisi tubuhnya, kondisi tubuh lawan jenisnya, serta menjaga dan menghindarkan anak dari kekerasan seksual. Oleh karena itu busy book ini dibuat peneliti agar dapat menghindarkan anak dari kekerasan seksual yang ada di sekitarnya. Tahap menentukan tema yang sesuai dengan kurikulum PAUD. Tema yang sesuai adalah tema tentang tubuhku. Pada saat guru mengajari anak tema tersebut, maka busy book dapat diberikan kepada anak, karena materi yang terdapat dalam busy book sejalan dengan tema tersebut.

Pada tahap penentuan materi, maka materi yang diberikan kepada anak usia dini untuk mengenalkan tentang pendidikan seks adalah materi yang berkaitan dengan kesesuaian materi dengan standar tingkat perkembangan kognitif anak. Kesesuaian tersebut penting dilakukan agar anak memahami materi yang disampaikan kepadanya. Selain itu juga busy book mengandung materi yang dapat mengenalkan pendidikan seks untuk anak seperti pengenalan anggota tubuh, pentingnya menjaga kebersihan tubuh, bagian tubuh yang tidak boleh disentuh dan apa yang harus dilakukan apabila ada orang lain yang menyentuh bagian tersebut. Materi lainnya yang terdapat di busy book adalah kesesuaian materi dengan lingkunp perkembangan anak.

Tahap perancangan. Tahap ini berisi penentuan alur, tokoh dan latar, setelah itu membuat skenario, menyiapkan materi, merancang tulisan, gambar dan suara. Busy book ini memiliki tokoh anak laki-laki dan anak perempuan dengan alur cerita dimana mereka dapat menyebutkan nama-nama anggota tubuhnya, dapat membersihkan dirinya sendiri dan dapat menyebutkan bagian apa saja yang tidak boleh disentuh oleh orang lain. Selain itu juga mereka dapat mengatakan "tidak" apabila ada orang lain yang menyentuh 4 bagian tubuhnya yang tidak boleh disentuh tersebut.

Perancangan materi yang dibuat dalam busy book ini sejalan dengan pendapat Alucyana, (2018), yaitu pendidikan seks diawali dengan memperkenalkan anggota tubuh. Anak diperkenalkan dengan berbagai anggota tubuh. Dengan memperkenalkan kepada anak seluruh anggota tubuhnya, anak mengetahui nama bagian-bagian yang terdapat dalam tubuhnya, letaknya dan selanjutnya anak diajari mengenai fungsi setiap anggota tubuh tersebut.

Selain itu juga materi yang terdapat dalam busy book juga mengandung pesan kepada anak untuk dapat menjaga kebersihan dirinya, terutama kebersihan alat genetalnya. Seperti yang dikemukakan oleh Rahma Nurfuati (2020), yang mengatakan bahwa toilet training dapat diajarkan kepada anak sejak usia 2 tahun. Pengenalan toilet training maksudnya adalah anak diajari bagaimana mengenali tanda-tanda untuk buang air kecil dan buang air besar, kemudian pergi ke toilet dan dapat membersihkan sendiri alat kelaminnya. Pengenalan toilet training diharapkan dapat mengajari anak untuk dapat membersihkan sendiri organ genetalnya dan tidak membolehkan orang lain untuk menyentuhnya.

Tahap pengembangan. Pada tahap ini peneliti melakukan wawancara dan memberikan angket kepada para guru-guru di TK Immanuel 2, dan TK Aisyah 3 Pontianak untuk mendapatkan data mengenai validasi ahli materi. Sedangkan ahli media berasal dari psikolog anak, dosen di PG-PAUD dan guru di TK Bina Sari Pontianak. Pengambilan data menggunakan 
wawancara dan angket tersebut sesuai dengan pendapat Siyoto Sandu (2015), yang mengatakan bahwa ada empat macam metode pengumpulan data; yaitu observasi, wawancara, dokumentasi, dan gabungan/triangulasi, dimana dalam penelitian ini, peneliti hanya menggunakan wawancara dan angket, dikarenakan keterbatasan waktu yang tersedia.

Uji coba efektifitas produk dilakukan pada 25 orang anak di TK Immanuel 2 Pontianak di kelompok TK A, dimana model penelitian ini adalah penelitian pengembangan. Menurut Kurniawan et al. (2017) model pengembangan 4D yaitu define, design, develop, dan disseminate dapat diadaptasikan menjadi $4 \mathrm{P}$ yaitu pendefinisian, perancangan, pengembangan, dan penyebaran. Dalam model pengembangan tersebut, diperlukan ujicoba produk untuk mengetahui efektifitas media yang dikembangkan.

Tahap penyebaran/diseminasi. Setelah mendapat masukan dari para validator media maupun materi, busy book tersebut akan diperbaiki, diberikan kepada beberapa TK, di upload ke youtube dan mendapatkan lisensi hak cipta. Hal tersebut sejalan dengan pendapat Kurniawan et al. (2017), dimana tahap akhir dalam penelitian dengan model pengembangan adalah diseminasi atau penyebaran hasil penelitian, sehingga masyarakat mengetahui dan dapat memanfaatkan hasil penelitian tersebut.

\section{SIMPULAN}

Busy book berbasis neurosains dinilai sangat layak untuk digunakan dalam mengenalkan pendidikan seks untuk anak usia dini, dimana busy book tersebut dinilai efektif dalam menarik perhatian anak, dapat memunculkan antusias anak, memunculkan keinginan turut berpartisipasi dalam aktivitas yang ada. Selain itu juga dengan adanya busy book tersebut anak dapat menjawab pertanyaan mengenai cara menjaga kebersihan anggota tubuh, dapat menyebutkan 4 bagian anggota tubuh yang tidak boleh disentuh oleh orang lain dan dapat menyebutkan apa yang harus dilakukan apabila ada orang menyentuh bagian yang tidak boleh disentuh

\section{UCAPAN TERIMA KASIH}

Ucapan terimakasih kami sampaikan kepada semua pihak yang telah berkontribusi dalam penelitian ini, khususnya kepada para guru-guru di TK Immanuel 2, TK Bina Sari, TK Gembala Baik, TK Cita Sahabat Mulia dan TK Aisyah 3 Pontianak, juga kepada Psikolog Anak dan dosen Psikologi di IAIN dan dosen-dosen PG-PAUD, FKIP, Universitas Tanjungpura.

\section{DAFTAR PUSTAKA}

Alucyana, Alucyana. 2018. "Pendekatan Metode Bermain Peran Untuk Pendidikan Seks Anak Usia Dini." Generasi Emas 1(1):1. https://doi.org/10.25299/ge.2018.vol1(1).2253

Arylien Ludji Bire, Etc. 2014. "Pengaruh Gaya Belajar Visual, Auditorial Dan Kinestetik Terhadap Prestasi Siswa." Jurnal Kependidikan 44:168-74.

Ibda, F. 2015. "Perkembangan Kognitif: Teori Jean Piaget." Intelektualita 3(1):242904. Jatmikowati, Angin, Ernawati. 2015. "A Model And Material of Sex Education For Early- AgedChildren." Cakrawala Pendidikan 132(3):434-48. https://doi.org/10.21831/cp.v3i3.7407

Kurniawan, Dian, Sinta Verawati Dewi, and Lembar Kerja. 2017. "Pengembangan Perangkat Pembelajaran Dengan Media Screencast- o-Matic Mata Kuliah Kalkulus 2 Menggunakan Model 4-D." Jurnal Siliwangi 3(1).

Kusnadi, Yahdi, and Mutoharoh. 2016. "Pengaruh Keterimaan Aplikasi Pendaftaran Online Terhadap Jumlah Pendaftar Di Sekolah Dasar Negeri Jakarta." Jurnal PARADIGMA XVIII(2):89-101.

Listiyana, Anik. 2010. "Peranan Ibu Dalam Mengenalkan Pendidikan Seks Pada Anak Usia Dini." Egalita, Jurnal Kesetaraan Dan Keadilan Gender 2.

Mufliharsi, Risa. 2017. "Pemanfaatan Busy Book Pada Kosakata Anak Usia Dini Di PAUD Swadaya PKK." Jurnal Metamorfosa. 
Nuari, Nian Afrian. 2017. "Analisis Perilaku Pencegahan Child Sexual Abuse Oleh Orang Tua Pada Anak Usia Sekolah." Jurnal Ilmu Kesehatan 5(1):01. https://doi.org/10.32831/jik.v5i1.106

Nurfuati, Rahma, and Zahrina Amelia. 2020. "Penggembangan Model Video Interaktif Dalam Mengembangkan Keterampilan Toilet Training Pada Anak Usia 4-5 Tahun." Jurnal Pendidikan Islam Anak Usia Dini 4(2):131-47.

Nurtaniawati, Nurtaniawati. 2017. "Peran Guru Dan Media Pembelajaran Dalam Menstimulasi Perkembangan Kognitif Pada Anak Usia Dini." Jurnal Tunas Siliwangi 3(1):1-20. https:// doi.org/10.32505/atfaluna.v1i1.769

Prasanti, Ditha. 2018. "Penggunaan Media Komunikasi Bagi Remaja Perempuan Dalam Pencarian Informasi Kesehatan." Jurnal Lontar 6 NO:13-21. https://doi.org/10.30656/lontar.v6i1.645

Roqib, Moh. 1970. "Pendidikan Seks Pada Anak Usia Dini." INSANIA: Jurnal Pemikiran Alternatif Kependidikan 13(2):271-86. https:/ / doi.org/10.24090/insania.v13i2.298

Saputri, Windriantari. 2015. "Peningkatan Kemampuan Berbicara Melalui Media Gambar Pada Anak Kelompok A Di TK Bener Yogyakarta." Jurnal Pendidikan Guru PAUD 13.

Sari, Ika Fajar. 2016. "Pengembangan Perangkat Pembelajaran Bahasa Indonesia Kelas $x$ Semester Gasal Berbasis Psychowriting Kurikulum 2013 Implementasi 2016." Pengembangan Perangkat Pembelajaran 1-6.

Siyoto Sandu, Sodik Ali. 2015. Dasar Metodologi Penelitian.

Solihin. 2015. "Pendidikan Seks Untuk Anak Usia Dini ( Studi Kasus Di TK Bina Anaprasa Melati Jakarta Pusat )." JURNAL JPSD (Jurnal Pendidikan Sekolah Dasar) (1):56-74. https://doi.org/10.26555/jpsd.v1i1.a1484

Wahyuni, Dewi. 2018. "Peran Orang Tua Dalam Pendidikan Seks Bagi Anak Untuk Mengantisipasi Lgbt." Jurnal Ilmiah Kesejahteraan Sosial XIV(LGBT):23-32. 